\title{
Diarrhoeal disease outbreaks associated with sanitation provision failures in refugee camps worldwide: a literature review
}

\author{
ESPÉRIE BURNET ${ }^{1}$ and JAMES W. RUDGE ${ }^{2}$
}

${ }^{1}$ MSc student at the University of London International Programme/London School of Hygiene and Tropical Medicine

\footnotetext{
${ }^{2}$ Assistant Professor in Infectious Disease Epidemiology at the Department of Global Health and Development, London School of Hygiene and Tropical Medicine; Adjunct Professor at the Faculty of Public Health, Mahidol University, Bangkok, Thailand
} 


\section{ABSTRACT}

Objectives: The objective of this review is to identify sanitation failures that have contributed to the occurrence of diarrhoeal disease outbreaks among displaced populations living in camps.

Methods: Three electronic databases (Medline, Embase, Global Health) and reference lists were searched for peer-reviewed literature using a systematic approach. Articles published since 1960 describing both diarrhoeal disease outbreaks and sanitation characteristics in camps hosting displaced populations were included. Evidence linking outbreaks to sanitationrelated factors was synthesised and critically appraised.

Results: The search yielded 608 articles, of which 12 met inclusion criteria. They described cholera and shigellosis outbreaks occurring in 21 different camps between 1974 and 2009 . Recurring contributing factors across outbreaks included a sudden population influx, inadequate provision or maintenance of latrines, sudden rains and insufficient safe water quantities. Most studies were descriptive only or did not consider sanitation-related exposures in risk factor analyses. However, two case-control studies found that cases were significantly more likely than controls to share latrines with several households. Two other case-control studies identified an increased risk of infection from exposure to drinking contaminated river or shallow well water.

Conclusions: Evidence from previous outbreak investigations illustrates how sanitation failures, particularly following population influxes, can contribute to the occurrence of diarrhoeal disease outbreaks in refugee camps. Further development and application of sanitation assessment tools and metrics would enable more robust evaluation of risks associated with specific sanitation-related exposures and the effectiveness of interventions. Recent guidelines address the identified risk factors but stakeholders should be aware of the impact of population dynamics. 
Keywords: Sanitation, water contamination, displaced populations, refugee camp, diarrhoeal disease outbreak, epidemic. 


\section{INTRODUCTION}

The United Nations High Commission on Refugees (UNHCR) estimates that the number of people displaced by war, famine, civil strife or natural disaster reached 68.5 million at the end of $2017,85 \%$ of whom are hosted in developing countries (UNHCR, 2018). About $40 \%$ of them live in camps, the majority of which are in Low and Middle Income Countries (LMICs), where resources and infrastructure are in short supply (UNHCR, 2018). Assistance from international agencies and non-governmental organisations (NGOs) helps provide basic services but funding is seldom sufficient to ensure that all needs are met (United Nations High Level Panel on Humanitarian Financing, 2016).

One of the most challenging, yet crucial, aspects of camp management is sanitation, which includes five stages: containment, collection, transport, treatment and final disposal or reuse (Bill \& Melinda Gates Foundation, 2010; USAID, 2016). A failure at any stage of the chain can contaminate soil and water, thus establishing a reservoir for a pathogen to spread not only within a camp, but also beyond its boundaries. In 1997, the Red Cross and Red Crescent Societies, in partnership with other NGOs, initiated the Sphere project in order "to develop a set of universal minimum standards in core areas of humanitarian response" (The Sphere Project, 2011), including Water, Sanitation and Hygiene (WASH) services. The Sphere Handbook, first published in 2000 , specifies the number of people per latrine that should not be exceeded (20) and the minimum per person safe water quantity (15 litres/day) that should be available, among other criteria for outbreak prevention (Campbell and Howard, 2012).

Yet, in October 2010, a cholera outbreak hit Haiti seven months after an earthquake displaced 1.5 million people (Schuller and Levey, 2014). It was later discovered that the pathogen had been imported from an endemic country and introduced by a pipe discharging human waste from a United Nations Stabilisation Mission in Haiti (MINUSTAH) camp into the Artibonite River (Piarroux et al., 2011), causing 480,000 cases and 7,000 deaths within a year (Piarroux and Faucher, 2012). The Haiti outbreak is an example of a sanitation failure leading to the spread of a pathogen into a susceptible population as a consequence of inadequate management of human excreta disposal by an organisation that had the means, awareness and responsibility to uphold standards and guidelines. 
30

Data from the UNHCR Health Information System have been analysed in studies examining water and sanitation provision and the associated diarrhoeal disease burden (Cronin et al., 2008, 2009; Hershey et al., 2011). Cronin et al. (2009) collected data from 130 camps and found that more than a quarter of them failed to meet sanitation standards in 2005. In another study by Cronin and colleagues (2008), covering 39 camps, 132,000 cases of diarrhoea were estimated to be "attributable to incomplete water and sanitation provision" out of an aggregated camp population of 1 million. From 2006 to 2010, diarrhoeal diseases were estimated to be associated with $7 \%$ of deaths and $10 \%$ of overall morbidity in children under five years of age living in 90 camps distributed across 16 countries (Hershey et al., 2011).

Several recent reviews examining the impact of WASH interventions on reducing the incidence of diarrhoeal diseases in low resource settings have highlighted a lack of published evidence regarding the effectiveness of sanitation-specific interventions (Brown et al., 2012; Ramesh et al., 2015; Blanchet et al., 2017). Their focus on interventions implies that outbreak investigations that searched for the cause of the outbreaks might not have been included. Examining the sanitation-related risk factors that contributed to past outbreaks could help the framing and evaluation of interventions and might guide future research. The aim of this review is to synthesize the findings of peer-reviewed articles that have documented both outbreak investigations and sanitation characteristics in camps hosting displaced populations over the last 60 years.

\section{METHODS}

\section{Search strategy and inclusion criteria}

A search for literature published in English and in French from 1960 to April 2018 was undertaken, using a systematic approach, in the Medline, Embase and Global Health databases on 25 April 2018. Each database was searched using the subject headings and keywords associated with the key concepts 'sanitation', 'diarrhoea' and 'refugee camp'. The Boolean operators OR and AND were used to link each subject heading with the associated 
keywords and to combine the three key concepts/keywords, respectively. Appendix A describes the full search strategy and search strings.

Articles were initially screened by title and abstract. Eligibility was determined in a stepwise approach based on whether articles met all of the following criteria: 1) a diarrhoeal disease outbreak was investigated; 2 ) the outbreak occurred in a camp hosting a displaced population; and 3) sanitation characteristics were described. Where abstracts did not provide sufficient information, full texts were retrieved and the same stepwise approach was used to determine final inclusion. In addition, reference lists of relevant articles were screened to identify further eligible papers based on the same criteria.

\section{Data extraction and analysis}

Data extraction, analysis and synthesis were conducted following the Preferred Reporting Items for Systematic Reviews and Meta Analyses (PRISMA) statement (Moher et al., 2009). For each included article, data was extracted on: study design; outbreak characteristics; person, place and time parameters; sanitation provision characteristics; measures of effect; and potential sources of bias. Information on contributing factors such as water source, quantity and quality, weather events, cultural factors and any other relevant information were also extracted. A summary table was developed to synthesize outbreak, camp and WASH characteristics, as well as any contextual factors that may have contributed to the outbreak's occurrence.

A critical appraisal of the evidence was conducted for each study using a common checklist adapted from the Critical Appraisal Skills Programme guidelines (CASP, 2017), from the Strengthening the Reporting of Observational Studies in Epidemiology (STROBE) statement (von Elm et al., 2007) and from Reingold's guidelines for outbreak investigations (Reingold, 1998) (see Appendix B: critical appraisal checklist).

In addition to the overall critical appraisal based on the checklist, the strength of the evidence linking sanitation failure and outbreak occurrence in each study was classified as possible, probable or strong based on the inclusion of a sanitation parameter in statistical analyses and/or the description of the mechanism for pathogen transmission in the epidemiological investigation (see Table 1). Sanitation variables were considered both within 
a camp and at the individual or household level to determine: a) whether identified cases were significantly more likely to have been exposed to sanitation-related risk factors; $b$ ) whether attack rates differed between populations with contrasting sanitation characteristics; and, c) whether the outbreak began within one incubation period from the time of the suspected sanitation failure.

Table 1: criteria for classifying the strength of the evidence linking sanitation failures and outbreak occurrence

\begin{tabular}{l|l}
\hline Possible & Circumstantial evidence linking sanitation failure to outbreak occurrence \\
\hline Probable & $\begin{array}{l}\text { Statistically significant association between exposure to a sanitation variable } \\
\text { and being a case found in univariate analysis. } \\
\text { Or descriptive epidemiological investigation suggests likely mechanism for } \\
\text { sanitation failure leading to drinking water contamination }\end{array}$ \\
\hline Strong & $\begin{array}{l}\text { Statistically significant association between exposure to sanitation variable } \\
\text { (e.g. person/latrine ratio, access to clean latrine, shared latrine as dichotomous } \\
\text { variable) and being a case found in multivariate analysis after adjusting for } \\
\text { other explanatory factors. } \\
\text { Or descriptive epidemiological investigation provides detailed description of } \\
\text { person, place and time parameters linking sanitation provision failure to the } \\
\text { outbreak. }\end{array}$ \\
\hline
\end{tabular}

\section{RESULTS}

\section{Study characteristics}

A total of 608 articles were identified through the systematic database search and screened by title/abstract: 561 were not eligible and 47 were examined further, of which 10 met inclusion criteria. The reference list search yielded an additional two studies, resulting in the inclusion of twelve articles in the review (see Figure 1). The artciles reported on 21 outbreaks that occurred between 1974 and 2009 (see Table 2 and Appendix C).

Two outbreaks took place near Dhaka, Bangladesh; one in 1974 among the landless rural population resettled after independence (Khan and Shahidullah, 1982), the other in 1978 in a camp hosting Burmese refugees fleeing civil war (Khan and Munshi, 1983). All the other outbreaks were in East Africa, along the Great Rift Valley. Of these, one took place in the Sudanese camp of Shagarab in 1985 among Ethiopian refugees fleeing famine (Mulholland, 
105 1985); four occurred during the Mozambican civil war in three camps along the Malawi106 Mozambican border in 1988 (Moren et al., 1991), 1990 (Swerdlow et al., 1997) and 1992 107 (Mulemba and Nabeth, 1994) and in a fourth camp in Zimbabwe in 1992 (Bradley et al., 1996). 
921 records from database search

Medline: 314

Embase: 416

Global Health: 191

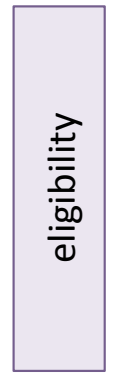

47 full texts retrieved and assessed for eligibility

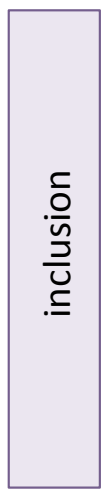

608 records screened by title/abstract removed

$\lceil\quad 561$ records excluded

- No diarrhoeal disease outbreak investigated: 492

- Not a camp setting: 38

- Sanitation not addressed: 31


37 records excluded

- No full text: 4

- No diarrheal disease outbreak investigated: 18

- Not a camp setting: 4

- Not enough information on

sanitation: 11 sanitation. 11 
One of the most severe cholera epidemics broke out in Goma, Zaire (now the Democratic Republic of the Congo, DRC), in July 1994, during the Rwandan civil war, infecting

112 close to 700,000 refugees. It was followed by an outbreak of bacillary dysentery caused by Shigella dysenteriae type 1 (Sd1); these two outbreaks were described in two articles (Goma Epidemiology Group, 1995; Bechen et al., 1996). One study described 11 Shigellosis outbreaks that occurred from 1993 to 1995 in camps in Tanzania, DRC (including the Goma outbreak) and Rwanda, using data collected by Médecins Sans Frontières (MSF) (Kernéis et al., 2009). Finally, two cholera epidemics occurred in Kakuma camp (Kenya) in 2005 (Shultz et al., 2009) and in 2009 (Mahamud et al., 2012). The camp had been established in 1991 to host refugees from neighbouring countries. The search did not yield any articles published after 2012 that met inclusion criteria.

Overall, the strength of evidence linking specific sanitation related factors with the occurrence of an outbreak, and with individual risk of infection in an outbreak, was assessed as strong in one study, probable in seven and possible in four (see Table 2). Four studies used a matched pair case-control design (Moren et al., 1991; Swerdlow et al., 1997; Shultz et al., 2009; Mahamud et al., 2012) but, of these, only two included a sanitation variable as an exposure (Shultz et al., 2009; Mahamud et al., 2012). The other two examined water source and contact with a specific location as exposures, considering sanitation-related risk factors as contributing to water contamination in the discussion only (Moren et al., 1991; Swerdlow et al., 1997). Of the eight other studies, one presented the results of a spatio-temporal statistical model comparing the same outbreak occurring in a camp and farm community

131 (Bradley et al., 1996) and the remaining seven were descriptive (Khan and Shahidullah, 1982; 132 Khan and Munshi, 1983; Mulholland, 1985; Mulemba and Nabeth, 1994; Goma Epidemiology Group, 1995; Bechen et al., 1996; Kernéis et al., 2009). 
134 Table 2: Study characteristics and critical appraisal summary

\begin{tabular}{|c|c|c|c|c|c|}
\hline $\begin{array}{l}\text { Author(s) } \\
\text { (publication } \\
\text { year) }\end{array}$ & $\begin{array}{c}\text { Country } \\
\text { Year of outbreak }\end{array}$ & Study design & $\begin{array}{c}\text { Epide } \\
\text { miolo } \\
\text { gical } \\
\text { curve }\end{array}$ & $\begin{array}{l}\text { Sanitation } \\
\text { as exposure }\end{array}$ & $\begin{array}{c}\text { Strength of } \\
\text { evidence linking } \\
\text { sanitation failure to } \\
\text { outbreak }^{\mathrm{a}}\end{array}$ \\
\hline $\begin{array}{c}\text { Khan \& } \\
\text { Shahidullah } \\
(1982) \\
\end{array}$ & $\begin{array}{c}\text { Bangladesh } \\
1974\end{array}$ & Descriptive & No & No & Possible \\
\hline $\begin{array}{c}\text { Khan \& } \\
\text { Munshi (1983) }\end{array}$ & $\begin{array}{c}\text { Bangladesh } \\
1978\end{array}$ & Descriptive & No & No & Possible \\
\hline $\begin{array}{c}\text { Mulholland } \\
(1985)\end{array}$ & $\begin{array}{c}\text { Sudan } \\
1985\end{array}$ & Descriptive & No & No & Probable \\
\hline $\begin{array}{c}\text { Moren et al. } \\
\text { (1991) }\end{array}$ & $\begin{array}{c}\text { Malawi } \\
1988 \\
\end{array}$ & $\begin{array}{c}\text { Matched } \\
\text { case control }\end{array}$ & Yes & Yes & Probable \\
\hline $\begin{array}{c}\text { Swerdlow et } \\
\text { al. } \\
(1997)\end{array}$ & $\begin{array}{c}\text { Malawi } \\
1990\end{array}$ & $\begin{array}{l}\text { Matched } \\
\text { case control }\end{array}$ & Yes & Yes & Probable \\
\hline $\begin{array}{l}\text { Mulemba \& } \\
\text { Nabeth (1994) }\end{array}$ & $\begin{array}{c}\text { Malawi } \\
1992\end{array}$ & Descriptive & No & No & Possible \\
\hline $\begin{array}{c}\text { Goma } \\
\text { Epidemiology } \\
\text { Group (1995) } \\
\end{array}$ & $\begin{array}{l}D R C \\
1994\end{array}$ & Descriptive & Yes & No & Probable \\
\hline $\begin{array}{l}\text { Bradley et al. } \\
\text { (1996) }\end{array}$ & $\begin{array}{c}\text { Zimbabwe } \\
1992\end{array}$ & $\begin{array}{l}\text { Statistical } \\
\text { modelling }\end{array}$ & Yes & No & Possible \\
\hline $\begin{array}{l}\text { Bechen et al. } \\
(1996)\end{array}$ & \begin{tabular}{|l}
$D R C$ \\
1994 \\
\end{tabular} & Descriptive & Yes & No & Probable \\
\hline $\begin{array}{l}\text { Kernéis et al. } \\
\text { (2009) }\end{array}$ & $\begin{array}{c}\text { Tanzania, DRC \& } \\
\text { Rwanda } \\
1993-94 \\
\end{array}$ & Descriptive & Yes & No & Probable \\
\hline $\begin{array}{l}\text { Schultz et al. } \\
\text { (2009) }\end{array}$ & $\begin{array}{l}\text { Kenya } \\
2005\end{array}$ & $\begin{array}{c}\text { Matched } \\
\text { case control }\end{array}$ & Yes & Yes & Strong \\
\hline $\begin{array}{l}\text { Mahamud et } \\
\text { al. (2012) }\end{array}$ & $\begin{array}{c}\text { Kenya } \\
2009\end{array}$ & $\begin{array}{l}\text { Matched } \\
\text { case control }\end{array}$ & Yes & Yes & Probable \\
\hline
\end{tabular}

a see table 1 for classification criteria

Only one study showed strong evidence of an association between a measured sanitation 138 parameter and the likelihood of being a case in multivariable statistical analysis. Three other studies 139 included sanitation as an exposure parameter but the evidence was not conclusive enough to

140 confirm the association. Among the eight remaining studies, those that showed the distribution of cases over time (epidemiological curve) and described a possible mechanism of transmission were given a higher score in the critical appraisal. 
Table 3: Outbreak characteristics

\begin{tabular}{|c|c|c|c|c|c|c|c|}
\hline $\begin{array}{l}\text { Author(s) } \\
\text { (publication } \\
\text { year) }\end{array}$ & $\begin{array}{l}\text { Camp (country) } \\
\text { Year of outbreak }\end{array}$ & $\begin{array}{l}\text { Pathogen (serotype) } \\
\text { Case definition }^{1}\end{array}$ & $\begin{array}{l}\text { Total camp } \\
\text { pop. (n) }\end{array}$ & $\begin{array}{c}\text { Total } \\
\text { cases }(n)\end{array}$ & AR (\%) & $\begin{array}{l}\text { Duration } \\
\text { (weeks) }\end{array}$ & $\begin{array}{c}\text { Recent } \\
\text { Pop } \\
\text { influx* }\end{array}$ \\
\hline $\begin{array}{c}\text { Khan and } \\
\text { Shahidullah } \\
(1982)\end{array}$ & $\begin{array}{c}\text { Dhaka (Bangladesh) } \\
1974\end{array}$ & $\begin{array}{c}\text { V. cholera } \\
\text { Syndromic, requiring IV } \\
\text { rehydration }\end{array}$ & 73,162 & 177 & $0.24^{2}$ & - & No \\
\hline $\begin{array}{c}\text { Khan and } \\
\text { Munshi (1983) }\end{array}$ & $\begin{array}{c}\text { Leda (Bangladesh) } \\
1978\end{array}$ & $\begin{array}{l}\text { V. cholera \& S. dysenteriae } \\
\text { Positive faecal culture }\end{array}$ & 17,695 & $\begin{array}{l}\text { Vc: } 128^{3} \\
\text { Sd: } 1,741^{4}\end{array}$ & $\begin{array}{l}\text { Vc: } 0.72^{5} \\
\text { Sd: } 9.84^{6}\end{array}$ & - & Yes \\
\hline $\begin{array}{l}\text { Mulholland } \\
\text { (1985) }\end{array}$ & $\begin{array}{c}\text { Shagarab (Sudan) } \\
1985\end{array}$ & $\begin{array}{c}\text { V. cholera (Inaba) } \\
\text { Syndromic }+ \text { direct stool } \\
\text { observation } \\
\text { Active case finding }\end{array}$ & 30,000 & 1,166 & 3.89 & 6 & Yes \\
\hline $\begin{array}{l}\text { Moren et al. } \\
\text { (1991) }\end{array}$ & $\begin{array}{c}\text { Mankhokwe (Malawi) } \\
1988\end{array}$ & $\begin{array}{c}\text { V. cholera (Inaba) } \\
\text { Diarrhoea, vomiting or collapse } \\
\text { due to dehydration } \\
\text { Active case finding }\end{array}$ & 29,745 & 784 & 2.60 & 9 & Yes \\
\hline
\end{tabular}

\section{Abbreviations: Vc: Vibrio cholera, Sd: Shigella dysenteriae} rehydration

Kernéis et al 2009) to 6 months (Khan and 6 months or less prior

${ }^{1}$ All case definitions imply admission to health care facility

${ }^{2}$ Weighted average of sections $A(A R=0.16), B(A R=0.40)$ and $C(A R=0.43)$

${ }^{3}$ Calculated based on $5.5 \%$ rectal swabs positive for cholera of a total of 2321 collected $(2321 / 100) \times 5.5=128$. Cultures limited to 10 per day. The authors do not mention whether one culture corresponds to one case.

${ }^{4}$ Calculated based on $75 \%$ rectal swabs positive for Shigella of a total of 2321 collected : $(2321 / 100) \times 75=1741$

${ }^{5}$ Calculated based on 128 inferred cholera cases and mean camp population: $(128 / 17,695) \times 100=3.80$

${ }^{6}$ Calculated based on 1741 inferred Shigella cases and mean camp population: $(1741 / 17,695) \times 100=9.84$ 
Table 3 (cont.): Outbreak characteristics

\begin{tabular}{|c|c|c|c|c|c|c|c|}
\hline $\begin{array}{c}\text { Author(s) } \\
\text { (publication } \\
\text { year) }\end{array}$ & $\begin{array}{l}\text { Camp (country) } \\
\text { Outbreak Year }\end{array}$ & $\begin{array}{c}\text { Pathogen } \\
\text { Case definition }\end{array}$ & $\begin{array}{l}\text { Total camp } \\
\text { pop (n) }\end{array}$ & $\begin{array}{c}\text { Total } \\
\text { cases }(n)\end{array}$ & AR (\%) & $\begin{array}{l}\text { Duration } \\
\text { (weeks) }\end{array}$ & $\begin{array}{l}\text { Recent } \\
\text { pop } \\
\text { influx* }\end{array}$ \\
\hline $\begin{array}{l}\text { Mulemba and } \\
\text { Nabeth (1994) }\end{array}$ & $\begin{array}{c}\text { Lisungwi } \\
\text { (Malawi) } \\
1992\end{array}$ & $\begin{array}{c}\text { Cholera } \\
\text { Syndromic } \\
\text { Active case finding }\end{array}$ & 51,930 & 3730 & 7.18 & - & Yes \\
\hline $\begin{array}{l}\text { Bradley et al. } \\
\text { (1996) }\end{array}$ & $\begin{array}{c}\text { Tongogara (Zimbabwe) } \\
\text { Farm (F) vs Camp (C) } \\
1992\end{array}$ & $\begin{array}{c}\text { V. cholera (Ogawa \& Inaba) } \\
\text { Syndromic }\end{array}$ & $\begin{array}{l}\text { C: } 48,000 \\
F: 8,000\end{array}$ & $\begin{array}{l}\text { C: } 1,155 \\
F: 436\end{array}$ & $\begin{array}{l}\text { C: } 2.41 \\
\text { F: } 5.50\end{array}$ & $\begin{array}{l}\text { C: } 18 \\
F: 21\end{array}$ & Yes \\
\hline $\begin{array}{c}\text { Goma } \\
\text { Epidemiology } \\
\text { Group (1995) } \\
\text { Bechen et al. } \\
\text { (1996) }\end{array}$ & $\begin{array}{l}\text { Goma (DRC) } \\
1994\end{array}$ & $\begin{array}{l}\text { V. cholera (Ogawa) } \\
\text { Diarrhoea, dehydration } \\
\begin{array}{c}\text { S. dysenteriae type } 1 \\
\text { bloody stool }\end{array}\end{array}$ & 800,000 & $\begin{array}{c}\text { Vc: } \\
70,000^{7} \\
\text { Sd1: } \\
15,543\end{array}$ & $\begin{array}{c}\text { Vc: } 7.30^{8} \\
\text { Sd1: - }\end{array}$ & 4 & Yes \\
\hline $\begin{array}{l}\text { Kernéis et al. } \\
\text { (2009) }\end{array}$ & $\begin{array}{c}11 \text { camps } \\
\text { (Tanzania, DRC, } \\
\text { Rwanda) 1993-94 }\end{array}$ & $\begin{array}{c}\text { S. dysenteriae type } 1 \\
\text { Diarrhoea + visible blood in stool }\end{array}$ & $\begin{array}{l}\text { Range: } \\
8,588 \text { to } \\
215,889\end{array}$ & 181,921 & 6 to 39 & 5 to 29 & Yes \\
\hline $\begin{array}{l}\text { Shultz et al. } \\
\text { (2009) }\end{array}$ & $\begin{array}{c}\text { Kakuma (Kenya) } \\
2005\end{array}$ & $\begin{array}{l}\text { V. cholera (Inaba) } \\
\text { Syndromic } \\
\text { Active case finding }\end{array}$ & 90,000 & 348 & 0.49 & 6 & Yes \\
\hline $\begin{array}{l}\text { Mahamud et } \\
\text { al. (2012) }\end{array}$ & $\begin{array}{c}\text { Kakuma (Kenya) } \\
2009\end{array}$ & $\begin{array}{l}\text { V. cholera (Inaba) } \\
\text { Syndromic } \\
\text { Active case finding }\end{array}$ & 62,015 & 163 & 0.27 & 12 & Yes \\
\hline
\end{tabular}

${ }^{7}$ Estimate from Bechen (1996). Goma Epidemiology group (1995) provides a range of between 58,000 and 80,000.

${ }^{8}$ Based on high population estimate of 800,000 and low estimate of total cases of 58,000.

The variation in case definitions prevented any comparisons between outbreaks. Outbreak duration and attack rates seemed to be 


\section{Outbreak characteristics}

Eighteen outbreaks occurred within six months of a population fleeing war, famine or drought, two soon after the transfer of a group from one camp to another and one three years after the population had been established in the camp. Vibrio cholerae 01 biotype El Tor, serotypes Inaba, Ogawa, or both were isolated from faecal specimens in 11 outbreaks. Three studies mentioned only "cholera" without further specification. Shigella dysenteriae type 1 (Sd1) was isolated in Goma (DRC) in 1994 shortly after the onset of the cholera outbreak, in Leda camp (Bangladesh), where cholera was also identified, and in all 11 dysentery outbreaks documented by MSF (see Table 3).

In the two articles describing the Goma outbreak, the authors calculated the number of cases retrospectively, based on the number of bodies collected in the streets of the town before surveillance could be put in place, and triangulated this estimate with clinic data and household surveys (Goma Epidemiology Group, 1995; Bechen et al., 1996). Apart from these two studies and that of Khan and Munshi (1983), who used positive faecal samples as a case definition, the number of cases was determined from health care facility records using syndromic case definitions. Five articles noted that active case finding was undertaken after the first cases were detected. None attempted to differentiate between primary and secondary cases (see table 3 ).

Total camp populations ranged from 8,588 to 215,589 and all but two studies provided an Attack Rate (AR), using total camp population as the denominator (see table 3). ARs were much lower in the cholera outbreaks, ranging from $0.24 \%$ in Dhaka (patients requiring IV rehydration) to $7.30 \%$ in Goma (all individuals presenting to the cholera treatment centre), compared with the dysentery outbreaks (range: 5.5\% in Kashusha to $39.1 \%$ in Kibumba, both in DRC, same case definition). Case definition specificity could have introduced a degree of selection bias as those who sought treatment a) had not yet died b) had severe enough symptoms to seek care and c) were aware of the presence of a treatment centre.

Where indicated, mean outbreak duration was 14 weeks, ranging from 4 to 29 weeks with the peak occurring between 6 and 43 days after the start of data collection (see Table 3 and Appendix C). Five studies showed a rapid increase in the number of cases within months or days of a population influx. Only two studies identified a potential index case, one of which 
was among new arrivals, but neither could confirm where, or from whom, the person had acquired the pathogen (see Appendix C).

Case Fatality Rates (CFR) for cholera were given in eight studies, and ranged from $0.37 \%$ in Lumashi to $6.5 \%$ in Goma. A large proportion of deaths were thought to be iatrogenic in two cholera outbreaks. Antibiotic resistance and inappropriate prescription practices were thought to have contributed to the high CFRs in 9 of the 11 Shigella outbreaks described by Kernéis et al. (2009).

\section{Sanitation characteristics and defecation practices}

Five studies reported a persons per latrine ratio, which ranged from 13 to 1,029 . The ratio was greater than 100 in six camps. Sphere standards, first published in 2000, recommend a maximum person per latrine ratio of 40 during the acute phase of a complex emergency (i.e. within the first three months of population displacement) and of 20 thereafter (The Sphere Project, 2011). The two studies that reported on outbreaks that occurred after these guidelines were published, both at Kakuma camp, either did not provide a ratio or reported the official figure of 13 persons per latrine and emphasized the great variability in latrine distribution within the camp (see Table 4).

Five articles described sanitation facility characteristics, which included sewerconnected toilets, ventilated and improved pit latrines, unprotected surface latrines and trench latrines. Rocky and/or volcanic soil limited or prevented the digging of latrines in the Goma and in Leda camps. Latrine emptying or excreta collection practices were mentioned only by Mahamud et al. (2012), who observed that a large number of latrines were full and non-functional without further description in the 2009 Kakuma outbreak. Two articles mentioned lack of latrine cleaning, which was under the responsibility of the users, as a barrier to utilisation. Open defecation in fields, bushes, the banks of ponds, rivers or lakes and/or compound grounds was reported in eight studies (see Table 4 and Appendix C). 
Table 4: Sanitation characteristics

\begin{tabular}{|c|c|c|c|c|}
\hline $\begin{array}{c}\text { Author(s) } \\
\text { (publication year) }\end{array}$ & $\begin{array}{l}\text { Camp } \\
\text { (Country) }\end{array}$ & $\begin{array}{c}\text { Persons per } \\
\text { latrine }(n)\end{array}$ & Latrine type & $\begin{array}{c}\text { Alternative } \\
\text { defecation } \\
\text { practices }\end{array}$ \\
\hline $\begin{array}{c}\text { Khan and } \\
\text { Shahidullah (1982) }\end{array}$ & $\begin{array}{c}\text { Dhaka } \\
\text { (Bangladesh) } \\
\text { sections } A, B, C\end{array}$ & $\begin{array}{l}\text { A: } 130 \\
\text { B: } 325 \\
\text { C: } 405\end{array}$ & $\begin{array}{c}\text { A: enclosed, } \\
\text { connected to sewer } \\
\text { B\&C: surface, } \\
\text { unprotected }^{1} \\
\end{array}$ & $\begin{array}{l}\text { A: - } \\
\text { B\&C: Open field, } \\
\text { ponds }\end{array}$ \\
\hline $\begin{array}{l}\text { Khan and Munshi } \\
\text { (1983) }\end{array}$ & $\begin{array}{c}\text { Leda } \\
\text { (Bangladesh) }\end{array}$ & 50 & Trench & - \\
\hline Mulholland (1985) & $\begin{array}{l}\text { Shagarab } \\
\text { (Sudan) }\end{array}$ & - & Trench & $\begin{array}{l}\text { Open field } \\
\text { Compound } \\
\text { ground }\end{array}$ \\
\hline Moren et al. (1991) & $\begin{array}{l}\text { Mankhokwe } \\
\text { (Malawi) }\end{array}$ & - & - & - \\
\hline $\begin{array}{c}\text { Swerdlow et al. } \\
\text { (1997) }\end{array}$ & $\begin{array}{l}\text { Nyamithuthu } \\
\text { (Malawi) }\end{array}$ & - & - & $\begin{array}{l}\text { Open field } \\
\text { Riverbed }\end{array}$ \\
\hline $\begin{array}{l}\text { Mulemba and } \\
\text { Nabeth (1994) }\end{array}$ & $\begin{array}{l}\text { Lisungwi } \\
\text { (Malawi) }\end{array}$ & $>10$ & Communal & - \\
\hline $\begin{array}{c}\text { Bradley et al. } \\
(1996)\end{array}$ & $\begin{array}{l}\text { Tongogara } \\
\text { (Zimbabwe) }\end{array}$ & C: 28 & $\begin{array}{c}\text { Ventilated } \\
\text { Improved } \text { pit }^{2}\end{array}$ & - \\
\hline $\begin{array}{c}\text { Kernéis et al. } \\
\text { (2009) }\end{array}$ & $\begin{array}{l}\text { Nsangwa } \\
\text { Kaduha } \\
\text { Rukundo } \\
\text { (Tanzania) } \\
\text { Benaco } \\
\text { Lumashi } \\
\text { (Rwanda) }\end{array}$ & $\begin{array}{c}60-120 \\
200 \\
- \\
- \\
20\end{array}$ & - & - \\
\hline $\begin{array}{c}\text { Goma Epi Group } \\
\text { (1995) } \\
\text { Bechen et al. } \\
\text { (1996) } \\
\text { Kernéis et al. } \\
\text { (2009) }\end{array}$ & $\begin{array}{l}\text { Mungunga } \\
\text { Kibumba } \\
\text { Katale } \\
\text { Kalehe } \\
\text { Kashusha } \\
\text { Inera } \\
\text { (DRC) }\end{array}$ & $\begin{array}{c}1029 \\
500 \\
184 \\
- \\
- \\
-\end{array}$ & Lake Kivu & $\begin{array}{l}\text { Open field } \\
\text { Open field } \\
\text { Open field } \\
- \\
- \\
-\end{array}$ \\
\hline Shultz et al. (2009) & $\begin{array}{l}\text { Kakuma } \\
\text { (Kenya) }\end{array}$ & $13^{3}$ & $\begin{array}{l}\text { Household } \\
\text { Communal }\end{array}$ & $\begin{array}{l}\text { Bushes } \\
\text { Riverbed }\end{array}$ \\
\hline $\begin{array}{l}\text { Mahamud et al. } \\
\text { (2012) }\end{array}$ & $\begin{array}{l}\text { Kakuma } \\
\text { (Kenya) }\end{array}$ & - & $\begin{array}{c}\text { Household } \\
\text { Communal } \\
\text { Some non-functional }\end{array}$ & $\begin{array}{l}\text { Bushes, Riverbed } \\
\text { Compound } \\
\text { ground }\end{array}$ \\
\hline
\end{tabular}

$217{ }^{1}$ No containment of human waste from environment, no covering or pit

$218{ }^{2}$ No further description given in text

$219{ }^{3}$ Wide variations in distribution throughout the camp, household latrines included in total 


\section{Sanitation-related risk factors for outbreak occurrence}

221

222

223

224

225

226

227

228

229

230

231

232

233

234

235

236

237

238

239

240

241

242

243

244

245

246

247

248

Delayed provision of sanitation facilities after a population influx

Insufficient latrine provision after a recent population influx in the camp was mentioned in six articles (see Table 5). The heterogeneity in case definitions prevented comparisons between cholera outbreaks but Kernéis et al. (2009) showed that, in the Shigella outbreaks, higher ARs were found in camps that had a higher persons per latrine ratio and where the humanitarian response was delayed or lacked capacity. In Goma, despite early warning (from international players present in the area) of potential large population displacements, the agencies on the ground received support only after the outbreak had been reported by international media (Goma Epidemiology Group, 1995; Bechen et al., 1996; Kernéis et al., 2009). In Leda camp, agencies arrived on the scene several months after the refugees were settled (Khan and Munshi, 1983). In Lisungwi, communal latrines were built when refugees first arrived but were insufficient (Mulemba and Nabeth, 1994).

Shultz et al. (2009) evaluated the association between "sharing a latrine with three or more households" and becoming a case, which yielded an Odds Ratio (OR) of 2.17 (95\% Cl: 1.01-4.68) after adjusting for recent arrival and water storage in a sealed container. Though recent arrivals had more than four times the odds of symptomatic disease (OR: $4.66,95 \% \mathrm{Cl}$ : 1.35-16.05), the authors could not establish with any certainty whether they introduced the pathogen into a non-immune population or provided a pool of susceptibles for an endemic strain. However, the sections of the camp that saw the highest ARs also had the lowest latrine coverage and hosted the majority of new arrivals (Shultz et al., 2009). In Nyamithuthu, Swerdlow et al. (1997) found that $86 \%$ of the cases had arrived three months prior to becoming infected.

In the 2009 Kakuma outbreak, sharing a communal latrine was associated with higher odds of becoming a case in bivariate analysis, with an OR of 3.33 (95\% Cl: 1.34-8.30) but was not found to be statistically significant in multivariate analysis (data not shown in article), which included only dirty water storage containers and hand washing with soap as covariates in the final multivariate model (Mahamud et al., 2012). Although the authors noted that 12,000 people had been transferred from another camp one month earlier, recent arrival was 
not found to be a significant risk factor (OR: 1.83; 95\% Cl: 0.68-4.96) (Mahamud et al., 2012). However, almost half of eligible cases could not be located for an interview and controls were excluded if any member of the compound had experienced diarrhoea as of two days after outbreak detection, thus introducing potential selection bias.

The high proportion of asymptomatic individuals in cholera-infected populations (Sack et al., 2004) implies a high risk of differential misclassification bias in the case-control studies. In the other articles, the risk of ecological fallacy (Carneiro and Howard, 2011) prevented the isolation of sanitation failure effects from water and hygiene-related factors when estimating exposure.

Open defecation and the use of unsafe water sources

Open defecation practices were described as contributing factors in nine outbreaks, as the areas that had been used for defecation were also used for drinking, washing and bathing in the context of limited water availability (see table 5). The daily per person quantity of safe water provided at the time of outbreak detection was given in seven studies and ranged from 0.2 to 20 Litres per person per day with only one camp meeting the minimum daily requirement set by Sphere of 15 Litres of water per person (The Sphere Project, 2011).

In Nyamithuthu, cases were s16 times more likely to have "visited the river" and to drink river water (OR: 16.1; 95\% Cl: 2.0-351.2) (Swerdlow et al., 1997). In contrast, Shultz et al. (2009), suspecting that the river might have been a common source of infection in the 2005 Kakuma outbreak, found that cases were not significantly more likely to drink river water compared with controls despite the riverbank having been used for defecation. However, they acknowledged that a high risk of recall and misclassification bias, an on-going education campaign and a small sample size, might have under-estimated the association.

Cultural factors were described in four studies. In Dhaka (Khan and Shahidullah, 1982) and Kakuma in 2005 (Shultz et al., 2009), populations migrating from rural areas were reported to have placed little value in the use of latrines, resorting to open defection instead, and to have shown little concern for the upkeep and maintenance of shared facilities. Visible human faeces were observed on compound grounds in Shagarab (Mulholland, 1985) and in 
277 Kakuma in 2009 (Mahamud et al., 2012), where the authors noted that some camp dwellers

278 considered children's faeces harmless.

279 Accidental water contamination

280 The most precise description of the mechanism by which drinking water was 281 contaminated by infected faeces was given by Mulholland (1985), who described tanker 282 trucks driving through a muddy field used for defecation before their tanks were filled in a 283 lake to supply the camp with drinking water. In the Mankhokwe outbreak, heavy rains 284 destroyed half the latrines 15 days before the first cases of cholera were detected and cases 285 were 4.5 times more likely than controls to use the water from shallow wells (95\% $\mathrm{Cl}: 1.0-20.9$, $286 \mathrm{p}=0.04)$; the distance between the surface of the water table and the bottom of nearby pit 287 latrines was less than 1 metre (Moren et al., 1991). In both outbreaks that occurred in 288 Bangladesh, heavy rain filled ditches and holes that had previously been used for defecation, 289 and camp residents were reported to have used the rain water for washing and bathing (Khan 290 and Shahidullah, 1982; Khan and Munshi, 1983). 
Table 5: Sanitation and water accessibility

\begin{tabular}{|c|c|c|c|c|c|}
\hline $\begin{array}{c}\text { Author(s) } \\
\text { (publication } \\
\text { year) }\end{array}$ & $\begin{array}{c}\text { Camp } \\
\text { (country) }\end{array}$ & $\begin{array}{l}\text { Persons } \\
\text { per } \\
\text { latrine (n) }\end{array}$ & $\begin{array}{l}\text { Safe water } \\
\text { quantity } \\
\text { (L/person/ } \\
\text { day) }\end{array}$ & $\begin{array}{l}\text { Defecation } \\
\text { at water } \\
\text { source }\end{array}$ & $\begin{array}{l}\text { Delazjed } \\
\text { response }\end{array}$ \\
\hline Sphere & & $<20$ & $>15$ & & \\
\hline $\begin{array}{l}\text { Khan and } \\
\text { Shahidullah } \\
\text { (1982) }\end{array}$ & $\begin{array}{l}\text { Dhaka A } \\
\text { Dhaka B } \\
\text { Dhaka C }\end{array}$ & $\begin{array}{l}130 \\
325 \\
405 \\
\end{array}$ & $\begin{array}{l}- \\
- \\
- \\
\end{array}$ & $\begin{array}{l}- \\
\text { yes } \\
\text { yes } \\
\end{array}$ & No \\
\hline $\begin{array}{l}\text { Khan and } \\
\text { Munshi (1983) }\end{array}$ & Leda & 50 & $\begin{array}{l}\text { "extremely } \\
\text { low" }\end{array}$ & yes & yes \\
\hline $\begin{array}{l}\text { Mulholland } \\
\text { (1985) }\end{array}$ & Shagarab & - & 10 & Yes & Yes \\
\hline $\begin{array}{l}\text { Moren et al. } \\
(1991)\end{array}$ & Mankhokwe & - & $\begin{array}{l}\text { "critical } \\
\text { shortages" }\end{array}$ & - & Yes \\
\hline $\begin{array}{l}\text { Mulemba and } \\
\text { Nabeth (1994) }\end{array}$ & Lisungwi & $>10$ & $\begin{array}{l}6-14 \\
4-12 \\
\end{array}$ & - & Yes \\
\hline $\begin{array}{l}\text { Goma Epi } \\
\text { Group (1995) } \\
\text { Bechen et al. } \\
(1996)\end{array}$ & Goma & - & 0.2 & Yes & Yes \\
\hline $\begin{array}{l}\text { Bradley et al. } \\
\text { (1996) }\end{array}$ & Tongogara & 28 & - & - & - \\
\hline $\begin{array}{l}\text { Swerdlow et al. } \\
\text { (1997) }\end{array}$ & Nyamithuthu & - & - & yes & yes \\
\hline $\begin{array}{l}\text { Kernéis et al. } \\
\text { (2009) }\end{array}$ & $\begin{array}{l}\text { Nsangwa } \\
\text { Kaduha } \\
\text { Rukundo } \\
\text { Benaco } \\
\text { Lumashi } \\
\text { Mungunga } \\
\text { Kibumba } \\
\text { Katale } \\
\text { Kalehe } \\
\text { Kashusha } \\
\text { Inera }\end{array}$ & $\begin{array}{l}60-120 \\
200 \\
- \\
- \\
20 \\
1029 \\
500 \\
184 \\
- \\
- \\
-\end{array}$ & $\begin{array}{l}20 \\
3 \\
- \\
3.7 \\
15 \\
1 \\
1 \\
1 \\
6 \\
2 \\
- \\
\end{array}$ & $\begin{array}{l}- \\
- \\
- \\
- \\
- \\
\text { Yes } \\
\text { Yes } \\
\text { Yes } \\
- \\
- \\
-\end{array}$ & $\begin{array}{l}- \\
- \\
- \\
\text { No } \\
\text { No } \\
\text { Yes } \\
\text { Yes } \\
\text { Yes } \\
\text { No } \\
\text { No } \\
\text { No }\end{array}$ \\
\hline $\begin{array}{l}\text { Shultz et al. } \\
\text { (2009) }\end{array}$ & Kakuma & 13 & $8-17$ & Yes & Yes \\
\hline $\begin{array}{l}\text { Mahamud et al. } \\
\text { (2012) }\end{array}$ & $\begin{array}{l}\text { Kakuma } \\
\text { Section } 2\end{array}$ & - & $9.8-12.2$ & Yes & Yes \\
\hline
\end{tabular}




\section{DISCUSSION}

294

295

296

297

298

299

300

301

302

303

304

305

306

307

308

309

310

311

312

313

314

315

316

317

318

319

320

321

322

The search for peer-reviewed literature yielded 12 articles, published between 1982 and 2012, describing diarrhoeal disease outbreaks and sanitation characteristics in 21 camps hosting displaced populations. The evidence of an association between specific sanitation failures and infection risk was difficult to isolate in the context of safe drinking water shortages. Nonetheless, based on the evidence found in these articles, three main sanitationrelated risk factors were identified as having contributed to pathogen transmission, both in isolation and concurrently: 1) lack of sanitation provision due to a delay in humanitarian response after a population influx; 2) open defecation in the proximity of lakes, rivers or ponds used for washing, bathing and drinking; and 3) direct contact between faecal sludge and water sources after heavy rains.

The focus on sanitation failures was motivated by recent reviews that found a lack of evidence on the effectiveness of sanitation-specific interventions in controlling communicable diseases during complex emergencies (Brown et al., 2012; Ramesh et al., 2015; Blanchet et al., 2017). Despite the low threshold for the level of detail on sanitation provision required for inclusion, only 12 articles met inclusion criteria, reflecting the dearth of published peer-reviewed outbreak investigations that evaluated exposure to sanitation-related parameters in camps. A limitation was to have excluded grey literature, where relevant evidence might have shown improvements - or lack thereof - in sanitation provision since the publication of Sphere guidelines.

The findings of the present review do not suggest that no outbreaks have occurred in camps since 2009. Rather, they show that very few published articles reporting on outbreak investigations examined sanitation-related factors, which is likely due to the difficulty in measuring individual-level exposure. A search on ProMED, an online report system for infectious disease outbreaks which is widely used internationally (Promedmail, no date), showed that, between 2009 and 2014 alone, 18 diarrhoeal disease outbreaks occurred in refugee camps. The lack of precision in these reports precluded their inclusion in this study however.

This confirms the need for further research, particularly when considering that the outbreaks that were investigated occurred in camps where a) health care services were in 
place, b) surveillance was under way and considered reliable and c) sanitation provision data was available. Given the high likelihood of publication bias, these outbreaks could have been quite different from others that were not detected, not documented in peer-reviewed journals, or in which surveillance was not systematic (Bruckner and Checchi, 2011). Future research should explore the use of more robust indicators reflecting latrine utilisation and condition as well as accessibility. Questionnaires should include items on whether the use of latrines is systematic, occasional and/or concurrent with open defecation practices. The conditions of the latrines used and whether users had any direct contact with faeces should also be documented.

Examining the environmental determinants of cholera outbreaks in inland Africa from 1970 to 2012, Rebaudet et al. (2013), noted the importance of drinking water contamination either through open defecation near water sources in the context of droughts or secondary to the flooding of latrines into shallow wells, which is consistent with the findings of this review. They also suggested that human behaviour and social factors, along with population mobility and migration, were more likely to explain geographical patterns than seasonality or the presence of an established environmental reservoir (Rebaudet et al., 2013).

All but one outbreak examined here took place within six months of the arrival of a population fleeing war, famine and/or drought, therefore in the context of a complex humanitarian emergency (Toole and Waldman, 1997). A delay in adapting sanitation capacity to a population influx would have increased the potential for direct contact with infected faeces and for subsequent water contamination, to which both new arrivals and existing camp dwellers would have been exposed (Lam et al., 2015). Cronin et al. (2009) have shown that, in camps where the persons per latrine ratio is greater than 30 , the percentage of the population with access to improved sanitation is approximately $10 \%$; this increases to $25 \%$ when the ratio is between 21 and 30. They also demonstrated that access to sanitation plays a more important role in controlling diarrhoea than access to water (Cronin et al., 2009).

The use of river, pond or lake water for domestic purposes, and for drinking in the context of insufficient safe water resources, would have exposed a susceptible population either to an existing environmental reservoir or, more likely, to a common source, established with the introduction of the pathogen by an infected individual. A similar mechanism of transmission was suspected in Juba, Sudan, in 2007, among refugees returning from camps 
354 (Centers for Disease Control and Prevention, 2009) and in Kenya, in 1994, among Somali 355 refugees and Kenyan nationals living in slums (lijima et al., 1995).

Most of the outbreaks reported on in this review occurred in established camps after a sudden influx of population. Given the location of current conflicts, civil strife and extreme weather conditions, it is likely that such population movements will continue in future as people migrate to existing camps, overwhelming santiation and water services that have been planned for temporary occupation and for a limited number of people. The creation of the Sphere project in 1997 (The Sphere Project, 2011) shows that the will to improve sanitation services in camps has been in place for at least twenty years. Yet in 2015, a WHO working panel on cholera control highlighted that progress in implementing these guidelines was slow, particularly in terms of anticipation and response during high-risk periods (Seukap Pena et al., 2016).

Adequate sanitation provision can contribute to the prevention not only of diarrhoeal disease outbreaks but also of vector borne diseases and hookworm, dracunculiasis and schistosomiasis infections as well (Esrey et al., 1991; Cairncross and Valdmanis, 2006). Compared with other WASH interventions, such as soap distribution, container chlorination and community education, sanitation provision in camps generally requires a greater degree of planning in order to be effective.

Camp dwellers should be involved in designing and building facilities in order to ensure they are appropriate in terms of customs and habits. Innovation in designing temporary shared facilities should be encouraged, funded and evaluated in terms of impact and effectiveness. More importantly, allocating resources and ensuring continuity of service, both for the initial construction of facilities and for their maintenance should not be neglected. To quote Francesco Checchi and colleagues (2007), "timely and appropriate relief, grounded in clearly outlined, scientifically sound reasoning, focusing discussion on substantive matters and reducing the scope for political manipulation" is paramount. Stakeholders should be aware of basic infectious disease epidemiology concepts and should mobilize the appropriate resources to ensure sanitation facilities are adapted to the camp context, as well as topography, weather patterns and cultural norms. 


\section{CONCLUSION}

384 A search for peer-reviewed articles describing both a diarrhoeal disease outbreak and 385 sanitation characteristics in refugee camp settings yielded 12 articles published over the past 38660 years. A number of sanitation-related factors were identified as having contributed to 387 outbreak occurrence, in particular delayed latrine provision following a population influx and 388 inadequate maintenance of existing facilities, which contributed to open defecation and 389 subsequent water contamination. However, few studies measured sanitation characteristics 390 in detail and only two considered them as exposures in risk factor analyses. Further research 391 using more robust measurement tools and greater collaboration between the WASH and 392 health sectors are necessary in order to design interventions that are adaptable, readily 393 available and culturally appropriate. Using in-country resources and involving the local 394 population in the design of sanitation infrastructure that will meet their needs will likely 395 encourage the use and maintenance of facilities, and therefore reduce the risk of disease 396 transmission. Though major actors of the humanitarian relief field have emphasised the role 397 of coordination, collaboration and accountability in upholding sanitation and camp 398 management standards, the role of population dynamics in pathogen transmission should be 399 highlighted in order to justify resource allocation, and to emphasise the necessity for funds 400 to be readily available. 


\section{BIBLIOGRAPHY}

Bechen, R., Boutin, J. P., Combes, D., Coue, J. C., Desfontaine, M., Lamarque, D., Milleliri, J. M., Merouze, F., Niel, L., Regis, R., Rey, J. L., Signoret, J. and Soares, J. L. (1996) ‘Cholera in Goma, July 1994', Revue d'Epidemiologie et de Sante Publique, 44(4), pp. 358-363.

Bill \& Melinda Gates Foundation (2010) Water, Sanitation \& Hygiene Fact Sheet. Available at: https://docs.gatesfoundation.org/documents/water-sanitation-hygiene-fact-sheet2010.pdf (last accessed: 20 October 2016).

Blanchet, K., Ramesh, A., Frison, S., Warren, E., Hossain, M., Smith, J., Knight, A., Post, N., Lewis, C., Woodward, A., Dahab, M., Ruby, A., Sistenich, V., Pantuliano, S. and Roberts, B. (2017) 'Evidence on public health interventions in humanitarian crises', Lancet, 390(10109), pp. 2287-2296. doi: 10.1016/S0140-6736(16)30768-1.

Bradley, M., Shakespeare, R., Ruwende, A., Woolhouse, M. E. J., Mason, E. and Munatsi, A. (1996) 'Epidemiological features of epidemic cholera (El Tor) in Zimbabwe', Transactions of the Royal Society of Tropical Medicine and Hygiene, 90(4), pp. 378-382.

Brown, J., Jeandron, A., Cavill, S. and Cumming, O. (2012) Evidence review and research priorities : Water, sanitation, and hygiene for emergency response.

Bruckner, C. and Checchi, F. (2011) 'Detection of infectious disease outbreaks in twenty-two fragile states, 2000-2010: a systematic review.', Conflict and health, 5(1), p. 13. doi: 10.1186/1752-1505-5-13.

Cairncross, S. and Valdmanis, V. (2006) 'Disease Control in Developing Countries: Chapter 41 Water Supply, Sanitation and Hygiene Promotion', Disease Control in Developing Countries, pp. $771-792$.

Campbell, F. and Howard, N. (2012) 'The Humanitarian System', in Howard, N., Sondorp, E., and Veen, A. M. ter (eds) Conflict and Health. Maidenhead : Open University Press, pp. 46- 
56.

Carneiro, I. and Howard, N. (2011) Introduction to Epidemiology. 2nd edn. Maidenhead: Open University Press.

Centers for Disease Control and Prevention (2009) 'Cholera outbreak--southern Sudan, 2007', Morbidity and mortality weekly report. United States, 58(13), pp. 337-341. doi: mm5813a3 [pii].

Checchi F, Gayer M, Freeman Grais R, Mills EJ. Public Health in crisis-affected populations, a practical guide for decision-makers. Humanitarian Practice Network. 2007;(61):1-57.

Critical Appraisal Skills Programme (2017) CASP (case control study checklist). Available at: http://www.casp-uk.net/casp-tools-checklists (last accessed: 2 April 2017).

Cronin, A. A., Shrestha, D., Cornier, N., Abdalla, F., Ezard, N. and Aramburu, C. (2008) 'A review of water and sanitation provision in refugee camps in association with selected health and nutrition indicators - The need for integrated service provision', Journal of Water and Health, 6(1), pp. 1-13. doi: http://dx.doi.org/10.2166/wh.2007.019.

Cronin, A. A., Shrestha, D., Spiegel, P., Gore, F. and Hering, H. (2009) 'Quantifying the burden of disease associated with inadequate provision of water and sanitation in selected subSaharan refugee camps', Journal of Water and Health, 7(4), pp. 557-568. doi: http://dx.doi.org/10.2166/wh.2009.089.

von Elm, E., Altman, D. G., Egger, M., Pocock, S. J. and Gøtzsche, P. C. (2007) 'The Strengthening the Reporting of Observational Studies in Epidemiology ( STROBE ) Statement : Guidelines for Reporting Observational Studies', PLOS ONE, 4(10), p. e296. doi: https://doi.org/10.1371/journal.pmed.0040296.

Esrey, S. A., Potash, J. B., Roberts, L. and Shiff, C. (1991) 'Effects of improved water supply and sanitation on ascariasis, diarrhoea, dracunculiasis, hookworm infection, schistosomiasis, and trachoma.', Bulletin of the World Health Organization, 69(5), pp. 609-21. doi: http://dx.doi.org/10.2147/IJWH.S77807. 
Goma Epidemiology Group (1995) 'Public health impact of Rwandan refugee crisis: what happened in Goma, Zaire, in July, 1994?', Lancet, 345(8946), pp. 339-344. doi: http://dx.doi.org/10.1016/S0140-6736\%2895\%2990338-0.

Hershey, C. L., Doocy, S., Anderson, J., Haskew, C., Spiegel, P. and Moss, W. J. (2011) 'Incidence and risk factors for Malaria, pneumonia and diarrhea in children under 5 in UNHCR refugee camps: a retrospective study.', Conflict and Health, 5(24), pp. 1-11. doi: 10.1186/1752-1505-5-24.

lijima, Y., Oundo, J., Taga, K., Saidi, S. and Honda, T. (1995) 'Simultaneous outbreak due to Vibrio cholerae and Shigella dysenteriae in Kenya', The Lancet. England: Elsevier, 345(8941), pp. 69-70. doi: 10.1016/S0140-6736(95)91197-9.

Kernéis, S., Guerin, P. J., von Seidlein, L., Legros, D. and Grais, R. F. (2009) 'A look back at an ongoing problem: Shigella dysenteriae type 1 epidemics in refugee settings in Central Africa (1993-1995)', PLoS ONE, 4(2), pp. 1-6. doi: 10.1371/journal.pone.0004494.

Khan, M. U. and Munshi, M. H. (1983) 'Clinical illnesses and causes of death in a Burmese refugee camp in Bangladesh', International Journal of Epidemiology, 12(4), pp. 460-464. doi: 10.1093/ije/12.4.460.

Khan, M. U. and Shahidullah, M. D. (1982) 'Role of water and sanitation in the incidence of cholera in refugee camps.', Transactions of the Royal Society of Tropical Medicine and Hygiene, 76(3), pp. 373-377. doi: 10.1016/0035-9203(82)90194-8.

Lam, E., McCarthy, A., Brennan, M., E., L., A., M., Lam, E., McCarthy, A. and Brennan, M. (2015) 'Vaccine-preventable diseases in humanitarian emergencies among refugee and internally-displaced populations', Human Vaccines and Immunotherapeutics, 11(11), pp. 2627-2636. doi: http://dx.doi.org/10.1080/21645515.2015.1096457.

Luque Fernández, M. Á., Mason, P. R., Gray, H., Bauernfeind, A., Fesselet, J. F. and Maes, P. (2011) 'Descriptive spatial analysis of the cholera epidemic 2008-2009 in Harare, Zimbabwe: A secondary data analysis', Transactions of the Royal Society of Tropical Medicine and Hygiene, 105(1), pp. 38-45. doi: 10.1016/j.trstmh.2010.10.001. 
Mahamud, A., Ahmed, J., Nyoka, R., Auko, E., Kahi, V. and Ndirangu, J. (2012) 'Epidemic cholera in Kakuma refugee camp, Kenya, the importance of sanitation and soap.', Journal of Infection in Developing Countries, 6(3), pp. 234-241.

Moher, D., Liberati, A., Tetzlaff, J., Altman, D. G. and Grp, P. (2009) ‘Preferred Reporting Items for Systematic Reviews and Meta-Analyses: The PRISMA Statement', PLoS Medicine, 6(7), p. e1000097. doi: 10.1371/journal.pmed1000097.

Moren, A., Stefanaggi, S., Antona, D., Bitar, D., Gastellu Etchegorry, M., Tchatchioka, M., Lungu, G., Etchegorry, M. G., Tchatchioka, M. and Lungu, G. (1991) ‘Practical field epidemiology to investigate a cholera outbreak in a Mozambican refugee camp in Malawi, 1988', Journal of Tropical Medicine and Hygiene, 94(1), pp. 1-7.

Mulemba, F. and Nabeth, P. (1994) 'Environmental sanitation for the control of cholera in Lisungwi Refugee Camp, Malawi', Waterlines, 12(4), pp. 9-11. doi: 10.3362/02628104.1994.016.

Mulholland, K. (1985) 'Cholera in Sudan: An account of an epidemic in a refugee camp in eastern Sudan, May-June 1985', Disasters, 9(4), pp. 247-258.

Piarroux, R., Barrais, R., Faucher, B., Haus, R., Piarroux, M., Gaudart, J., Magloire, R. and Raoult, D. (2011) 'Understanding the cholera epidemic, Haiti', Emerging Infectious Diseases, 17(7), pp. 1161-1167. doi: 10.3201/eid1707.110059.

Piarroux, R. and Faucher, B. (2012) 'Cholera epidemics in 2010: Respective roles of environment, strain changes, and human-driven dissemination', Clinical Microbiology and Infection. European Society of Clinical Infectious Diseases, 18(3), pp. 231-238. doi: 10.1111/j.1469-0691.2012.03763.x.

Promedmail (no date). Available at: https://www.promedmail.org/ (last accessed: 30 November, 2018).

Ramesh, A., Blanchet, K., Ensink, J. H. J. and Roberts, B. (2015) 'Evidence on the effectiveness of water, sanitation and hygiene (WASH) interventions on health outcomes in 
humanitarian crises: a systematic review.', PLOS ONE, 10(9), pp. 1-20. doi: 10.1371/journal.pone.0124688.

Rebaudet, S., Sudre, B., Faucher, B. and Piarroux, R. (2013) 'Environmental determinants of cholera outbreaks in inland africa: A systematic review of main transmission foci and propagation routes', Journal of Infectious Diseases, 208(SUPPL. 1), pp. S46-S54. doi: 10.1093/infdis/jit195.

Reingold, A. (1998) 'Outbreak investigations-A perspective.', Emerging Infectious Diseases, 4(1), pp. 21-27.

Sack, D. A., Sack, R. B., Nair, G. B. and Siddique, A. (2004) 'Cholera', The Lancet, 363(9404), pp. 223-233. doi: 10.1016/S0140-6736(03)15328-7.

Schuller, M. and Levey, T. (2014) 'Kabrit ki gen twòp mèt: Understanding gaps in WASH services in Haiti's IDP camps', Disasters. M. Schuller, 38(S1), pp. S1-S24. doi: 10.1111/disa.12053.

Seukap Pena, E., Bwire, G., Dzotsi, E., Bonnet, M. C. and Hessel, L. (2016) ‘New momentum in prevention, control and elimination of cholera in Africa: priority actions identified by affected countries', The Weekly Epidemiological Record, 24(91), pp. 305-316. doi: 10.1016/j.actatropica.2012.04.013.

Shultz, A., Omollo, J. O., Burke, H., Qassim, M., Ochieng, J. B., Weinberg, M., Feikin, D. R. and Breiman, R. F. (2009) 'Cholera outbreak in Kenyan refugee camp: risk factors for illness and importance of sanitation.', American Journal of Tropical Medicine and Hygiene, 80(4), pp. 640-645. doi: 80/4/640 [pii].

Swerdlow, D. L., Malenga, G., Begkoyian, G., Nyangulu, D., Toole, M., Waldman, R. J., Puhr, D. N. D. and Tauxe, R. V (1997) 'Epidemic cholera among refugees in Malawi, Africa: treatment and transmission.', Epidemiology and Infection, 118(3), pp. 207-214. doi: http://dx.doi.org/10.1017/S0950268896007352.

The Sphere Project (2011) Humanitarian Charter and Minimum Standards in Humanitarian 
response. 3rd edn. Bourton on Dunsmore: Practical Actrion Publishing. doi: ISBN 978-1908176-00-4.

Toole, M. J. and Waldman, R. J. (1997) 'The Public Health Aspects of Complex Emergencies and Refugee Situations', Annual Review of Public Health, 18(1), pp. 283-312. doi: 10.1146/annurev.publhealth.18.1.283.

UNHCR (2018) Global Trends: Forced Displacement in 2017. Available at: http://www.unhcr.org/globaltrends2017/ (last accessed: 27 June 2018).

United Nations High Level Panel on Humanitarian Financing (2016) Too Important to fail addressing the humanitarian financing gap. Report to the secretary general., World Humanitarian Summit. Available at: https://reliefweb.int/report/world/high-level-panelhumanitarian-financing-report-secretary-general-too-important-fail (last accessed: 26 April 2017).

USAID (2016) Sanitation: Water and Development Strategy Implementation Brief, Washington, DC: USAID. 


\section{APPENDICES:}

\section{A. Detailed search strategy}

\begin{tabular}{|l|l|}
\hline Steps & Search terms \\
\hline Sanitation (concept A) \\
\hline 1 & $\begin{array}{l}\text { Subject headings } \\
\text { Medline, Embase: Sanitation; risk factors } \\
\text { Global health: Sanitation; latrines }\end{array}$ \\
\hline 2 & $\begin{array}{l}\text { Keywords } \\
\text { Sanitation OR latrine* OR toilet* OR WASH OR excr?eta disposal OR hygiene OR } \\
\text { defecat* OR f?eces OR water OR risk factor }\end{array}$ \\
\hline 3 & 1 OR 2 $\rightarrow$ all results for concept A \\
\hline Diarrhoeal disease outbreak (concept B) \\
\hline 4 & $\begin{array}{l}\text { Subject headings } \\
\text { Medline, Embase: Diarrhea AND epidemic } \\
\text { Global health: Infectious diseases }\end{array}$ \\
\hline 5 & $\begin{array}{l}\text { Keywords } \\
\text { (Diarrh* OR Cholera* OR Dysenter* OR Shigell* OR E* Coli OR Rotavirus OR } \\
\text { Norovirus OR Astrovirus OR Salmonell* OR Amoeb*) }\end{array}$ \\
\hline 6 & 4 OR 5 $\rightarrow$ all results for concept B \\
\hline 7 & 3 AND 6 $\rightarrow$ all results for concepts A and B \\
\hline Refugee camps (concept C) \\
\hline 8 & $\begin{array}{l}\text { Subject headings } \\
\text { Medline, Embase: Refugee OR refugee camp } \\
\text { Global Health: refugees }\end{array}$ \\
\hline 10 & $\begin{array}{l}\text { Keywords } \\
\text { Refugee* OR internally displaced person* OR IDP OR Displace* }\end{array}$ \\
\hline 11 & 8 OR 9 $\rightarrow$ all results for concept C \\
\hline 13 & 3 AND 10 $\rightarrow$ all results for concepts B and C \\
\hline & 3 AND 6 AND 10 $\rightarrow$ all results for concepts A and B and C \\
\hline & \\
\hline 10 &
\end{tabular}


B. Critical appraisal checklist (All items scored equally. Overall score attributed based on percentage of criteria met)




36. Are the results coherent with other available evidence?

37. Can the results be used to inform stakeholders?

38. Can these results be used to make recommendations? 


\section{Appendix C: Article Summary Table}

\begin{tabular}{|c|c|c|c|c|c|}
\hline $\begin{array}{l}\text { Author(s) } \\
\text { (publication } \\
\text { year) } \\
\text { Design }\end{array}$ & $\begin{array}{l}\text { Country, } \\
\text { camp name } \\
\text { (population) }\end{array}$ & $\begin{array}{l}\text { Outbreak } \\
\text { dates \& } \\
\text { pathogen }\end{array}$ & $\begin{array}{l}\text { Study population, case } \\
\text { definition \& data source }\end{array}$ & Outcome measures & Risk factors \\
\hline $\begin{array}{l}\text { Bechen et al. } \\
\text { (1996) } \\
\text { Descriptive }\end{array}$ & $\begin{array}{l}\text { Zaire } \\
\text { Goma } \\
(800,000)\end{array}$ & $\begin{array}{l}\text { July to } \\
14 / 08 / 1994 \\
\text { Vibrio } \\
\text { cholerae } \\
\text { (Ogawa) }\end{array}$ & $\begin{array}{l}\text { Case: Bodies of deceased } \\
\text { collected, watery } \\
\text { diarrhoea and/or } \\
\text { dehydration. } \\
\text { Data source: } \\
\text { dispensaries, cholera } \\
\text { wards }\end{array}$ & $\begin{array}{l}\text { AR: } 10 \% \text { (estimated by } \\
\text { authors) } \\
\text { Mortality rate: } \\
\text { Katalé: } 41,3 / 10,000 \\
\text { Kibumba: } 28,1 / 10,000 . \\
85-90 \% \text { attributable to } \\
\text { diarrhoea. }\end{array}$ & $\begin{array}{l}\text { Volcanic soil- cannot dig latrines } \\
\text { Lake Kivu only water source. } \\
\text { Drinking water: } 0.2 \mathrm{~L} / \text { person/day mid July, increased to } \\
2 \mathrm{~L} / \text { person/day in late July and } 5 \mathrm{~L} / \text { person/day in August } \\
\text { but decrease in number of cases before increase in water } \\
\text { distribution. } \\
\text { Civil war in Rwanda. Late humanitarian response despite } \\
\text { predictability of outbreak. }\end{array}$ \\
\hline $\begin{array}{l}\text { Bradley et al. } \\
\text { (1996) } \\
\text { Descriptive }\end{array}$ & $\begin{array}{l}\text { Zimbabwe } \\
\text { Tongogara } \\
(n=48,000)\end{array}$ & $\begin{array}{l}1992 \\
\text { Vibrio } \\
\text { cholerae } \\
\text { (Ogawa \& } \\
\text { Inaba) }\end{array}$ & $\begin{array}{l}\text { Case: "symptomatic", } \\
\text { WHO definition (1992) } \\
\text { Compares camp to } \\
\text { commercial farming } \\
\text { community } \\
\text { no info on data source }\end{array}$ & $\begin{array}{l}\text { Cases: } 1,155 \text { (camp) vs } \\
436 \text { (farm) } \\
\text { AR: } 2.4 \% \text { (calculated } \\
\text { based on data provided) } \\
\text { Doubling time in camp: } \\
1.2 \text { days in first } 11 \text { days. } \\
\text { Doubling time in farm: } \\
4.3 \text { days in first } 30 \text { days. }\end{array}$ & $\begin{array}{l}\text { Camp: Ventilated and improved latrines, } 28 \\
\text { people/latrine } \\
\text { boreholes, lagoons, river and irrigation canal. } \\
\text { Safe water sources: } 1 \text { borehole/10,000 people in camp vs } \\
1 \text { borehole/320 people in farm } \\
\text { Women of childbearing age and children at greatest risk. } \\
\text { Civil unrest and drought in Mozambique. Camp run by } \\
\text { Zimbabwe government and UNHCR, established in } 1983 .\end{array}$ \\
\hline $\begin{array}{l}\text { Goma } \\
\text { Epidemiology } \\
\text { Group (1994) } \\
\text { Descriptive }\end{array}$ & $\begin{array}{l}\text { Zaire } \\
\text { Katale } \\
(\mathrm{n}=80,000) \\
\text { Kibumba } \\
\text { ( } \mathrm{n}=180,000) \\
\text { Mugunga } \\
\text { ( } \mathrm{n}=150,000)\end{array}$ & $\begin{array}{l}\text { Early July- } \\
14 \text { August } \\
1994 \\
\text { Vibrio } \\
\text { cholerae } \\
\text { (Ogawa) } \\
\text { \& Shigella } \\
\text { dysenteriae } \\
\text { type } 1\end{array}$ & $\begin{array}{l}\text { Case: Non-specific. } \\
\text { UNHCR definition } \\
\text { Sources: agencies that } \\
\text { collected bodies, health } \\
\text { facilities, agencies caring } \\
\text { for unaccompanied } \\
\text { children, UNHCR, cluster } \\
\text { survey }\end{array}$ & $\begin{array}{l}\text { AR: } 7.3 \% \text { (estimate for } \\
\text { all refugees in Goma, } \\
\text { not specific to camps) } \\
\text { Mugunga: } 88 \% \text { deaths } \\
\text { from diarrhoeal disease, } \\
57 \% \text { diarrhoeal deaths } \\
\text { due to cholera }\end{array}$ & $\begin{array}{l}\text { Rocky, volcanic soil with poor drainage - cannot dig } \\
\text { latrines, wells or graves. } \\
\text { Open defecation predominant } \\
\text { Lake is main water source } \\
\text { All ages equally affected. } \\
\text { Civil war in Rwanda. Late humanitarian response. } \\
\text { Lack of security. Former Rwandan political and military } \\
\text { leaders in camp control population. }\end{array}$ \\
\hline
\end{tabular}




\section{Appendix C: Article Summary Table}

\begin{tabular}{|c|c|c|c|c|c|}
\hline $\begin{array}{l}\text { Author(s) } \\
\text { (publication } \\
\text { year) } \\
\text { Design }\end{array}$ & $\begin{array}{l}\text { Country, } \\
\text { camp name } \\
\text { (population) }\end{array}$ & $\begin{array}{l}\text { Outbreak } \\
\text { dates \& } \\
\text { pathogen }\end{array}$ & $\begin{array}{l}\text { Study population, case } \\
\text { definition \& data source }\end{array}$ & Outcome measures & Risk factors \\
\hline $\begin{array}{l}\text { Kernéis et al. } \\
\text { (2009) } \\
\text { Descriptive }\end{array}$ & $\begin{array}{l}\text { Rwanda, } \\
\text { Tanzania, } \\
\text { DRC (11 } \\
\text { camps) } \\
\text { Population } \\
\text { range: } 8,588 \\
\text { to } 215,889\end{array}$ & $\begin{array}{l}\text { Nov 1993- } \\
\text { Feb } 1995 \\
\text { Shigella } \\
\text { dysenteriae } \\
\text { type } 1\end{array}$ & $\begin{array}{l}\text { Any person with } \\
\text { diarrhoea (passage of } 3 \\
\text { or more watery or loose } \\
\text { stools in past } 24 \text { hours) } \\
\text { and visible blood in the } \\
\text { stool (WHO def.) } \\
\text { Compares camps in } 3 \\
\text { countries by camp size as } \\
\text { proxy for logistical } \\
\text { complexity } \\
\text { Source: MSF surveillance } \\
\text { data }\end{array}$ & $\begin{array}{l}\text { Mean ARs by camp size: } \\
\text { small: } 18.3 \%(+/-9.9), \\
\text { medium: } 13.5 \%(+/-4.8) \text {, } \\
\text { large: } 28.1 \%(+/-9.4)\end{array}$ & $\begin{array}{l}\text { Tanzania: drinking water \& latrines available within first } \\
\text { few days, sphere standards met } \\
\text { Goma (DRC): person/latrine ratios Katale: } 184 ; \text { Kibumba; } \\
500 \text { Mugunga: } 1029 \text {, Water sources: streams, lake. } \\
\text { Bukavu (DRC): good organisation of camp site } \\
\text { Rwanda: variable. } \\
8 \text { of } 11 \text { outbreaks occurred in the dry season, all within } 3 \\
\text { months of arrival of refugees. } \\
\text { ARs higher among <5 age group } \\
\text { Civil wars in Burundi and Rwanda. Outbreaks occur within } \\
3 \text { months of refugee arrival. Difference in ARs attributed } \\
\text { to camp management. }\end{array}$ \\
\hline $\begin{array}{l}\text { Khan and } \\
\text { Munshi } \\
\text { (1983) } \\
\text { Descriptive }\end{array}$ & $\begin{array}{l}\text { Bangladesh } \\
\text { Leda } \\
(\mathrm{n}=17,695)\end{array}$ & $\begin{array}{l}1978 \\
\text { Shigella } \\
\text { dysenteriae } \\
\text { type 1: } 75 \% \\
\text { Cholera: } \\
5.5 \%\end{array}$ & $\begin{array}{l}\text { Cases: patients admitted } \\
\text { to diarrhoea clinic. } \\
\text { 2,321 stool samples } \\
\text { collected and analysed } \\
\text { (not from all cases) } \\
\text { Sources: clinics, public } \\
\text { health office in camp }\end{array}$ & $\begin{array}{l}\text { Number of cases and AR } \\
\text { not given \& cannot be } \\
\text { calculated with } \\
\text { available data } \\
60 \% \text { all illness due to } \\
\text { diarrheal disease. } \\
29.9 \% \text { rectal swabs } \\
\text { positive }\end{array}$ & $\begin{array}{l}356 \text { Trench latrines (ratio 50:1), dug by refugees } \\
\text { Rocky ground, hand pump tube wells cannot be sunk. } \\
\text { Water supplied by tanker truck } \\
\text { Heavy rains, Ditches \& ponds used for washing \& bathing } \\
\text { 10,000 new arrivals. } \\
\text { Burmese refugees arrived in first quarter of 1978. Camps } \\
\text { officially opened in April/May. }\end{array}$ \\
\hline
\end{tabular}




\section{Appendix C: Article Summary Table}

\begin{tabular}{|c|c|c|c|c|c|}
\hline $\begin{array}{l}\text { Author(s) } \\
\text { (publication } \\
\text { year) } \\
\text { Design }\end{array}$ & $\begin{array}{l}\text { Country, } \\
\text { camp name } \\
\text { (population) }\end{array}$ & $\begin{array}{l}\text { Outbreak } \\
\text { dates \& } \\
\text { pathogen }\end{array}$ & $\begin{array}{l}\text { Study population, case } \\
\text { definition } \& \text { data source }\end{array}$ & Outcome measures & Risk factors \\
\hline $\begin{array}{l}\text { Khan and } \\
\text { Shahidullah } \\
\text { (1982) } \\
\text { Descriptive }\end{array}$ & $\begin{array}{l}\text { Bangladesh } \\
\text { Dhaka camp } \\
\text { A }(n=49,675), \\
\text { camp B } \\
(n=11,375) \& \\
\\
\text { camp C } \\
(n=12,112)\end{array}$ & $\begin{array}{l}1974 \text { and } \\
1975 \\
\text { Vibrio } \\
\text { cholerae }\end{array}$ & $\begin{array}{l}\text { Case: Patient admitted to } \\
\text { ICDDR, } \mathrm{B}^{1} \\
\text { Source: } 1974 \text { camp } \\
\text { census (total } \\
\text { population), ICDDR, } \mathrm{B}^{1} \\
\text { records. }\end{array}$ & $\begin{array}{l}\text { ARs } \\
\text { A: } 1.61 / 1,000^{2} \\
\text { B: } 3.95 / 1,000 \\
\text { C: } 4.29 / 1,000\end{array}$ & $\begin{array}{l}\text { Camp A: latrines connected to sewer, water piped. (ratio } \\
\text { 130:1) } \\
\text { Camps B \& C: built in 1971, no planning for sanitation or } \\
\text { drinking water: Latrines consist of fenced surface without } \\
\text { pit or covering. Some built on bank of pond. Ratio camp B } \\
\text { 325:1, camp C: } 405: 1 . \\
\text { Open defecation common, use of river water \& surface } \\
\text { water after rain. } \\
\text { Homogenous cultural and socioeconomic background } \\
\text { Landless rural population refugees after independence of } \\
\text { Bangladesh (1971) }\end{array}$ \\
\hline $\begin{array}{l}\text { Mahamud } \\
(2012) \\
\text { Matched } \\
\text { case-control } \\
\text { (93 pairs) }\end{array}$ & $\begin{array}{l}\text { Kenya } \\
\text { Kakuma } \\
(n=62,015)\end{array}$ & $\begin{array}{l}18 \text { Sep - } 15 \\
\text { Dec } 2009 \\
\text { Vibrio } \\
\text { cholerae } \\
\text { (Inaba) }\end{array}$ & $\begin{array}{l}\text { Cases: WHO definition in } \\
\text { any camp resident }>2 \\
\text { y.o. admitted to } \\
\text { treatment centre with } \\
\text { onset of illness after } 01 \\
\text { Oct } 2009 \\
\text { Controls matched on } \\
\text { location and age } \\
\text { Sources: camp records, } \\
\text { treatment centre, } \\
\text { population survey }\end{array}$ & $\begin{array}{l}\text { Total cases: } 163 \\
\text { AR: } 2.7 / 1,000 \text { overall } \\
\text { AR: } 9.5 / 1,000 \text { in } \\
\text { Kakuma2 area } \\
\text { CFR: } 1.8 \%\end{array}$ & $\begin{array}{l}\text { Bivariate analysis: } \\
\text { Sharing communal latrine } \mathrm{OR}=3.33(95 \% \mathrm{Cl}: 1.34-8.30, \\
\mathrm{p}=0.001) \\
\text { Human faeces visible on ground of compound } \mathrm{OR}=6.50 \\
(95 \% \mathrm{Cl} 1.47-28.8, \mathrm{p}=0.04) \\
\text { Open defecation common, children's faeces considered } \\
\text { harmless } \\
\text { Water sources: shallow wells in riverbed, stagnant water } \\
\text { at tap stand } \\
\text { Long-standing camp. } 12,000 \text { new arrivals from Dadaab } \\
\text { camp } 1 \text { month prior. }\end{array}$ \\
\hline
\end{tabular}

${ }^{1}$ ICDDR, B: International Centre for Diarrhoeal Disease Research, Bangladesh 


\section{Appendix C: Article Summary Table}

\begin{tabular}{|c|c|c|c|c|c|}
\hline $\begin{array}{l}\text { Author(s) } \\
\text { (publication } \\
\text { year) } \\
\text { Design }\end{array}$ & $\begin{array}{l}\text { Country, } \\
\text { camp name } \\
\text { (population) }\end{array}$ & $\begin{array}{l}\text { Outbreak } \\
\text { dates \& } \\
\text { pathogen }\end{array}$ & $\begin{array}{l}\text { Study population, case } \\
\text { definition \& data source }\end{array}$ & Outcome measures & Risk factors \\
\hline $\begin{array}{l}\text { Moren et al. } \\
\text { (1991) } \\
\text { Matched- } \\
\text { pair case- } \\
\text { control } \\
\text { (51 pairs) }\end{array}$ & $\begin{array}{l}\text { Malawi } \\
\text { Mankhokwe } \\
(n=29,745)\end{array}$ & $\begin{array}{l}15 \text { March - } \\
17 \text { May } \\
1988 \\
\text { Vibrio } \\
\text { cholerae } \\
\text { (Inaba) }\end{array}$ & $\begin{array}{l}\text { Case: "Person with an } \\
\text { acute onset of profuse } \\
\text { watery stools or profuse } \\
\text { vomiting or collapse due } \\
\text { to dehydration", who } \\
\text { was treated in the } \\
\text { camp's cholera } \\
\text { treatment centre } \\
\text { Controls: randomly } \\
\text { selected \& matched for } \\
\text { age, sex, and location } \\
\text { Source: cholera } \\
\text { treatment centre, } \\
\text { household survey }\end{array}$ & $\begin{array}{l}\text { Total cases: } 784 \\
\text { AR: } 2.6 \% \text { (range: } 0.9- \\
\text { 5.1) } \\
\text { AR higher in Market } \\
\text { section throughout and } \\
\text { among 5-14 age group } \\
\text { in market section: } 6.7 \% \\
\text { CFR: } 3.3 \%\end{array}$ & $\begin{array}{l}\text { Univariate analysis: } \\
\text { Lack of communal latrines at market } \\
\text { Water table } 5 \mathrm{~m} \text { below surface, latrines } 3-4 \mathrm{~m} \text { deep. } \\
5 \text { of } 24 \text { wells positive for faecal coliforms. } \\
\text { Shallow wells vs boreholes used: } \mathrm{OR}=4.5(95 \% \mathrm{Cl} 1.0-20.9 \text {, } \\
\mathrm{p}=0.04) \\
\text { Contact with market } \mathrm{OR}=3.5(95 \% \mathrm{Cl}=0.7-16.9, \mathrm{p}=0.09) \\
\text { No association with food exposure. } \\
\text { End of rainy season. Heavy rains } 15 \text { days prior: half } \\
\text { latrines destroyed. } \\
\text { Recent gathering of } 30,000 \text { refugees. } \\
400,000 \text { Mozambican refugees flee to Malawi. } \\
\text { Established camp. }\end{array}$ \\
\hline $\begin{array}{l}\text { Mulemba } \\
\text { and Nabeth } \\
\text { (1994) } \\
\text { Descriptive }\end{array}$ & $\begin{array}{l}\text { Malawi, } \\
\text { Lisungwi, } \\
\\
\text { Luwani } \\
\text { ( } n=35,790) \& \\
\text { Ndelema } \\
\text { ( } n=14,140)\end{array}$ & $\begin{array}{l}25 \text { May } \\
1992-01 \\
\text { March } \\
1993 \\
\text { Vibrio } \\
\text { cholerae }\end{array}$ & $\begin{array}{l}\text { Admitted to the cholera } \\
\text { camp for "acute and } \\
\text { profuse watery stools } \\
\text { and dehydration needing } \\
\text { IV rehydration" }\end{array}$ & $\begin{array}{l}\text { Cases: } 3,730 \\
\text { AR: } 7.34 \% \\
\text { CFR: } 2.39 \%\end{array}$ & $\begin{array}{l}\text { Communal latrines, built when refugees first arrived. } \\
\text { After beginning of outbreak, latrines built to reach quota } \\
\text { of } 10 \text { people per latrine. Unknown initial ratio. } \\
\text { No upkeep until team is hired to clean. } \\
\text { Water insufficient, supplemented by trucked-in water. } \\
\text { Household containers chlorinated at distribution point. } \\
\text { Describes interventions to stop outbreak, written by MSF } \\
\text { physicians. } \\
\text { Mozambican civil war and drought. New camp. }\end{array}$ \\
\hline
\end{tabular}




\section{Appendix C: Article Summary Table}

\begin{tabular}{|c|c|c|c|c|c|}
\hline $\begin{array}{l}\text { Author(s) } \\
\text { (publication } \\
\text { year) } \\
\text { Design }\end{array}$ & \begin{tabular}{|l|} 
Country, \\
camp name \\
(population)
\end{tabular} & $\begin{array}{l}\text { Outbreak } \\
\text { dates \& } \\
\text { pathogen }\end{array}$ & $\begin{array}{l}\text { Study population, case } \\
\text { definition \& data source }\end{array}$ & Outcome measures & Risk factors \\
\hline $\begin{array}{l}\text { Mulholland } \\
\text { (1988) } \\
\text { Descriptive }\end{array}$ & 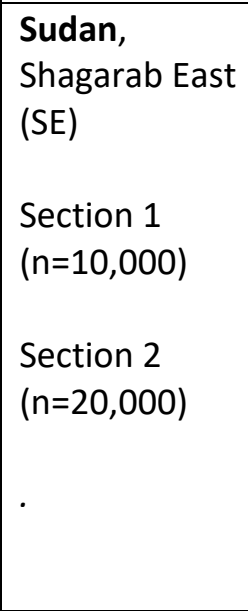 & $\begin{array}{l}\text { 15 May- } \\
30 \text { Jun } \\
1985 \\
\text { Vibrio } \\
\text { cholerae } \\
\text { (Inaba) }\end{array}$ & $\begin{array}{l}\text { "rice water stools" } \\
\text { (observed by nursing } \\
\text { staff), cold extremities, } \\
\text { profound dehydration } \\
\text { Source: clinic records, } \\
\text { door-to-door case finding } \\
\text { by health workers }\end{array}$ & $\begin{array}{l}\text { Cases S1: } 287 \\
\text { Cases S2: } 879 \\
\text { AR S1: } 2.9 \% \\
\text { AR S2: } 4.5 \%\end{array}$ & $\begin{array}{l}\text { Trench latrines, poorly utilized, scattered at camp } \\
\text { periphery } \\
\text { Open defecation on compound ground (children \& ill } \\
\text { adults, at night) \& in muddy fields. } \\
\text { Water trucked in from nearby dam. Bladder tanks filled } \\
\text { after driving through field used for defecation. } \\
\text { Clay soil, poor drainage. Road built through camp without } \\
\text { drainage provisions. Rainstorm } 3 \text { days prior. } \\
\text { 4-year-old boy with vomiting \& diarrhoea during } \\
\text { transport to SE2). } \\
\text { Famine in Ethiopia. } 20,000 \text { Refugees in two transit camps } \\
\text { transferred during month prior to start of outbreak. }\end{array}$ \\
\hline $\begin{array}{l}\text { Schultz et al. } \\
\text { (2009) } \\
\text { Matched } \\
\text { case-control } \\
\text { (90 } \\
\text { cases } / 170 \\
\text { controls) }\end{array}$ & $\begin{array}{l}\text { Kenya } \\
\text { Kakuma } \\
(n=90,000)\end{array}$ & $\begin{array}{l}\text { April } 2005 \\
\text { Vibrio } \\
\text { cholerae } \\
\text { (Inaba) }\end{array}$ & $\begin{array}{l}\text { Cases: "Any person of } \\
\text { any age with profuse, } \\
\text { effortless watery } \\
\text { diarrhoea ( } 3 \text { or more } \\
\text { stools per } 24 \text { hours) } \\
\text { admitted to the IRC } \\
\text { cholera ward between } \\
01 / 4 \text { and } 30 / 06 / 2005 \text { ". } \\
\text { Includes }<5 \text { age group. } \\
\text { Controls: matched by age } \\
\text { and location within camp } \\
\text { Sources: hospital } \\
\text { records, survey }\end{array}$ & $\begin{array}{l}\text { Total cases: } 348 \\
\text { AR overall: } 4.9 / 1,000 \\
\text { AR Kakuma } 2: \\
\text { 15.9/1,000 } \\
\text { AR area } 57 \text { of Kakuma } 1 \text { : } \\
\text { 15.0/1,000 } \\
\text { AR area } 58 \text { of Kakuma: } \\
\text { 12.1/1,000 }\end{array}$ & $\begin{array}{l}\text { Multivariable analysis: } \\
\text { - Sharing a latrine with } 3 \text { more households OR=2.17 } \\
\text { (95\%Cl: } 1.01-4.68) \\
\text { - Recent arrival adjusted OR=4.66 ( } 95 \% \mathrm{Cl}: 1.35-16.05) \text {. } \\
\text { New arrivals placed in Kakuma } 2 \\
\text { Lack of latrines where cases clustered (average ratio for } \\
\text { camp: } 13: 1 \text { - wide variations). } \\
\text { Upkeep by camp dwellers. } \\
\text { Boreholes provide } 8-17 \mathrm{~L} / \text { person/day (estimate accounts } \\
\text { for leakage and uses other than domestic) } \\
\text { Cases not more likely than controls to use water from } \\
\text { riverbed. } \\
\text { Long standing camp (established in 1991) IRC provides } \\
\text { health and sanitation services. Coordination by ministry of } \\
\text { health and UNHCR. }\end{array}$ \\
\hline
\end{tabular}




\section{Appendix C: Article Summary Table}

\begin{tabular}{|c|c|c|c|c|c|}
\hline $\begin{array}{l}\text { Author(s) } \\
\text { (publication } \\
\text { year) } \\
\text { Design }\end{array}$ & $\begin{array}{l}\text { Country, } \\
\text { camp name } \\
\text { (population) }\end{array}$ & $\begin{array}{l}\text { Outbreak } \\
\text { dates \& } \\
\text { pathogen }\end{array}$ & $\begin{array}{l}\text { Study population, case } \\
\text { definition } \& \text { data source }\end{array}$ & Outcome measures & Risk factors \\
\hline $\begin{array}{l}\text { Swerdlow et } \\
\text { al. (1997) } \\
\text { A: Matched } \\
\text { case-control } \\
\text { (50 pairs) } \\
\text { B: } \\
\text { Unmatched } \\
\text { case-control } \\
\text { (47 } \\
\text { patients/137 } \\
\text { households) }\end{array}$ & $\begin{array}{l}\text { Malawi } \\
\text { Nyamithuthu } \\
\text { ( } n=57,000 \text { on } \\
15 / 10,74,000 \\
\text { on } 15 / 11 \text { ) }\end{array}$ & $\begin{array}{l}23 \text { Aug - } 15 \\
\text { Dec } 1990 \\
\text { Vibrio } \\
\text { cholerae } \\
\text { (Inaba) }\end{array}$ & $\begin{array}{l}\text { Cases (A and B): } \\
\text { "diarrhoeal illness in a } \\
\text { person admitted to an IV } \\
\text { treatment tent at } \\
\text { Nyamithuthu camp } \\
\text { between } 23 \text { August and } \\
15 \text { December, 1990". } \\
\text { Controls A: matched by } \\
\text { age, sex and date of } \\
\text { arrival. } \\
\text { Controls B: cluster- } \\
\text { survey, door-to-door } \\
\text { household selection. } \\
\text { Source: treatment tent } \\
\text { records, camp } \\
\text { registration records. }\end{array}$ & $\begin{array}{l}\text { Overall cases: } 6,114 \\
\text { Admitted to IV } \\
\text { treatment tent: } 1,931 \\
\text { AR (requiring IV } \\
\text { treatment) =2.4\% } \\
\text { CFR (among IV } \\
\text { treated)=3.5\% }\end{array}$ & $\begin{array}{l}\text { Univariate analysis: Obtaining drinking water from river: } \\
\text { OR=3.0 (95\%Cl: } 1.4-6.4) \\
\text { Multivariable analysis: Visited river and drank river water: } \\
\text { Adjusted OR=16.1 (2.0-31.2) } \\
\text { Open defecation in fields and at river predominant. } \\
\text { Drilled wells but critical water shortages leading to river } \\
\text { water use. Extreme heat. } \\
86 \% \text { cases arrived } 3 \text { months prior. } 52 \%<16 \text { days prior. } \\
\text { New arrivals located at greater distance from well with } \\
\text { no access to latrines. } \\
\text { Cholera isolated in pooled water sample from } 4 \\
\text { households. } \\
\text { Mozambican refugees fleeing armed conflict. Camp } \\
\text { opened in } 1988, \text { planned for } 50,000 \text {. Sudden, unexpected } \\
\text { influx of } 20,000 \text { refugees from } 15 / 10 \text { to } 15 / 11 / 1990 \text {. } \\
\text { Fourth outbreak of cholera in } 2 \text { years. }\end{array}$ \\
\hline
\end{tabular}

